\title{
A Portrait About Writing Explanatory Skills of Fifth-Grade Elementary School
}

\author{
Bening Sri Palupi ${ }^{1, a^{*}}$, Slamet Subiyantoro ${ }^{1, b}$, and Rukayah ${ }^{1, c}$ \\ ${ }_{1}^{1}$ Postgraduate and Faculty of Teachers Training and Education, Universitas Sebelas Maret, 57126, Indonesia \\ a beningsip@student.uns.ac.id; b s.biyantoro@yahoo.co.id; c ruyakah.pgsd@yahoo.co.id \\ *Corresponding Author \\ Whatsapp number [0895393535323]
}

How to Cite : Palupi, B., S., Subiyantoro, S., Rukayah, R. (2019).A Portrait About Writing Explanatory Skills of Fifth-Grade Elementary School. International Journal for Educational and Vocational Studies, 1 (7), 733-738

\section{ARTICLE HISTORY}

Received: 11 August 2019

Revised: 21 September 2019

Accepted: 26 October 2019

\section{KEYWORDS}

Writing Explanatory Skills;

Elementary School;

\begin{abstract}
Indonesia has implemented the 2013 curriculum as a text-based learning framework. The text is used as a defender of science. The logical consequence, language skills are an absolute requirement for students so that they can achieve learning goals. On the other hand, writing is the highest skill in the language. Therefore, the study was aimed to describe the explanatory writing skills of fifth-grade elementary students. This research is a descriptive qualitative study using a sample of fifth-grade students in public elementary schools in the city of Surakarta, Central Java, Indonesia. Data collection techniques using documents and interviews. Source triangulation is used as data validity. The results showed that the greatest difficulty students had in writing explanations was writing cohesive and coherent sentences and paragraphs. They are only able to write their ideas without regard to syntactic rules. These writing skills involve students' metacognitive skills which also reflect other language skills such as listening and reading. This research output will be useful for academics and practitioners in determining the right learning approach to improve the success of text-based learning or the 2013 curriculum.
\end{abstract}

This is an open access article under the CC-BY-SA license.

\section{INTRODUCTION}

Recently, Indonesia has implemented a new curriculum, the 2013 curriculum. The curriculum uses text as an interdisciplinary science. Minister of Education and Culture Regulations number 24 (2016) revealed that fifth-grade students are required to be able to present the results of information classification based on what aspects, where, when, who, why and how. In the 2013 curriculum, students are confronted with authentic texts both oral and written. Through a text-based curriculum, students are expected to be skilled in language when they express their knowledge and ideas both verbally and in writing (Gu, 2017, p. 157).

The logical consequence of text-based learning in the 2013 curriculum is that language skills are an absolute requirement for successful learning. Language skills consist of listening, speaking, reading and writing. These four skills complement each other. However, writing skills are language skills at the highest level. Writing skills mastered someone after mastering the skills of listening, speaking, and reading (Slamet, 2017, p. 105). Therefore, we choose writing skills as a research variable which will also contribute to the extent of the success of text-based learning applied in the 2013 curriculum. Through variable writing skills, the child has also passed through learning other language skills. This is what will affect the quality of writing.

Writing can be said as a learning model because writing as a process that leads to the development of student knowledge that reflects student feedback (Chen, Hand, \& Mcdowell, 2013, p. 748). Therefore, before writing, the writer must master the subject or topic to be written so that he is able to put the problem/discussion into writing. Kusmana revealed the basic purpose of writing is to communicate in writing, solving problems, providing explanations/information, and pleasing the reader through creativity in writing (Kusmana, 2014, pp. 19-21).

On the other hand, writing is also done in various stages. In order for the writing to be neat and correct it must go through the following three steps namely pre-writing when writing, and post-writing (revising, 
editing, and presenting). Pramenulis is a writer doing various activities, for example, finding ideas, titles, types of writing, making a framework, and gathering materials. When writing i.e., it starts with describing ideas in the form of sentences and paragraphs which are arranged into a single composition. Post-writing consists of three, namely revising various aspects such as structure and linguistic structure, editing according to the references used, presenting in printed and non-printed forms (Slamet, 2017, pp. 117-119). Writing steps are also interrelated and interdependent and can also change the order of stages during the process (Tanyeli Zeki \& Kuter, 2017).

Writing requires broad insight because before the writer pours his ideas he is required to know things related to the topic. Therefore, reading competence is an important and necessary aspect for students. This is not only useful for language development but also for literacy (Dağ, 2017). Writing is also an ongoing skill. The higher the level of one's school, the better writing skills than the previous one. Verbal understanding and general information also appear significantly in 4th-grade elementary school. In this class, students begin to build short paragraphs and move on to essays and story development (Decker, Roberts, Roberts, Stafford, \& Eckert, 2016, p. 623). Based on this, the cognitive abilities of 5 th-grade students can be considered more ready to meet the cognitive needs needed in writing explanations. This is what underlies us choosing fifth-grade students as a research sample.

On the other hand, writing an explanation is writing a text describing the processes associated with natural, social, scientific, cultural phenomena and so on (Priyatni, 2014, p. 82). Therefore, students must have sufficient knowledge about the phenomena to be written in the text. This makes the explanation genre categorized as a text that challenges students' academics (Figueroa, Meneses, \& Chandia, 2018) and involves higher-order thinking skills (Li, Gobert, \& Dicker, 2017, p. 177).

Each type of text has its own characteristics, Kitcher (1989, pp. 417-420) revealed the structure of explanatory texts namely, 1) allows the title for an explanatory theory to elaborate the question of why thus showing the actual relationship; (2) explanation as a description of causes. The relevance relationship in the actual explanation is a causal relationship, an explanation identifying the cause; (3) the cause of the "why" question and explanation of the cause. This starts with certain facts and events. Each question has a draft as the topic. The level of difference between the single question "why" is a series of designs between topics of the question "why" so that it shows the similarity of the various designs on some of the features or objects described in the topic. Mahsun (2014: 98) argues that explanations in complex or complete explanation texts must contain the following structure: (1) title, (2) general statement, (3) explanatory sequence, and (4) conclusions.

Therefore, we conducted a study to describe the explanatory writing skills in 5th-grade elementary school students. In addition to the types of texts that challenge academic ability, the topic of the human circulatory system that is applied allows us to find out students' scientific knowledge. This is where we can find out the extent of the success of text-based learning applied in the 2013 curriculum. We can also find out other students' language skills such as listening, speaking, and reading. Regarding his assessment, we refer to Nurgiyantoro (2013, pp. 440-442) who argues that there are five aspects assessed in the essay namely the content of the ideas expressed, content organization, vocabulary, language development, and mechanics.

\section{METHODS}

This study was conducted on 31 fifth grade students of the 2017/2018 school year, SDN Manahan, Surakarta City, Indonesia. This research is a qualitative descriptive study. The data source used was an explanation of the fifth-grade students at Manahan Elementary School. Data collection techniques using documents and interviews. The writing guidelines that we write are based on opinion Nurgiyantoro (2013, pp.440-442). Although we did not make direct observations, the observation assessment guidelines are based on (Arikunto, 2013, p. 281) as a reference in measuring the success of text-based learning in the 2013 curriculum. The percentage of learning success is $0-39 \%$ is failed, $40-55 \%$ is less, $56-65 \%$ is enough, $66-79$ is good, and $80-100 \%$ is excellent.

We also conducted data validity by triangulating techniques and sources, namely analyzing student writing in accordance with predetermined assessment criteria based on the theory used and linking it to the results of interviews through Milles \& Huberman's interactive analysis. The interactive analysis consists of four stages, namely data collection, data reduction, data presentation, and drawing conclusions or verification. Triangulation is done by bringing together several indicators that are causally related (Milles \& Huberman, 1992, p. 436).

\section{RESULTS AND DISCUSSION}

This study analyzes explanatory texts made by fifth-grade students in elementary schools. There are five aspects included in the evaluation of essays, namely the content of ideas, organization of content, vocabulary, language development, and mechanics. The five aspects of the evaluation essay refer to Nurgiyantoro (2013, p. 440-442) Each aspect consists of four criteria, namely good, enough, middle, and lowest. Nurgiyantoro has also determined the scoring for each of these criteria. We adapt it to the characteristics of explanatory texts. Table 1 is t result of the assessment in each aspects.

Table 1. Mean Percentage of Explanatory Writing Skill Evaluation's

\begin{tabular}{cccccc}
\hline Aspects & Good & Enough & Middle & Lowest & Average \\
\hline $\begin{array}{c}\text { Content } \\
\text { ideas }\end{array}$ & 0 & 48.3 & 42 & 9.6 & 68.7 \\
\hline $\begin{array}{c}\text { Conten } \\
\text { organization }\end{array}$ & 9.6 & 25.8 & 51.6 & 13 & 62.4 \\
\hline Vocabulary & 13 & 29 & 38.7 & 19.3 & 63.5 \\
\hline
\end{tabular}




\begin{tabular}{cccccc}
\hline $\begin{array}{c}\text { Language } \\
\text { development }\end{array}$ & 9.6 & 25.8 & 42 & 22.5 & 56.25 \\
\hline Mechanic & 9.6 & 38.7 & 29 & 22.5 & 63.2 \\
\hline
\end{tabular}

Table 1 shows that only a few students were able to meet the criteria both in writing essays from all aspects of essay writing skills assessment. This can be seen in the good criteria column, there are not $10 \%$ of students who are able to meet the assessment indicators. At most only fulfilled by the vocabulary aspects, namely $13 \%$ of students who have good vocabulary mastery.

In addition, table 1 also shows that the average percentage achieved above $56 \%$. According to the Arikunto learning observation evaluation (2013, p.281), this percentage has reached a quite successful category. Although only 1 aspect is able to reach the good category, namely content ideas. Below we describe the explanation of each aspect of writing essay skill assessment.

\subsection{Content Ideas}

Table 1 shows that there were no students who could write the contents of ideas properly. They are unable to express the question of why and how. The combination of content and linguistic analysis does require students' scientific concepts and language in constructing explanations on a particular topic (Seah, 2016). Even so, there were at least $48.3 \%$ of students who were able to express the contents of ideas sufficiently. The explanatory text skills document shows that students only explain the definition and function of the organs needed in the human circulatory system. They have not shown a causal relationship between organs. Even though the explanatory text contains an explanation of the state of something caused by something else that has happened before (Maryanto, 2013, p. 1).

Similarly, disorders that can attack the human circulatory system. Students are only able to write various kinds of diseases. The definition of the disease is also still very limited. As many as $42 \%$ of students also do the same thing when writing about the process of human blood circulation. The explanation they wrote is also incomplete. Even so, the average results of students in expressing the contents of their ideas have reached $68.7 \%$. That is, most students are able to write various contents of ideas related to topics even though the ideas they write are still incomplete.

The results of interviews with students also showed that students were able to convey the contents of ideas when asked about topics. The teacher also claimed that it was easier to convey the contents of ideas verbally than to convey them in writing. Because of the inherent difficulties in generating and organizing ideas and bringing them together harmoniously, writing is considered the most difficult skill among other language skills (Kılıç, Genç, \& Bada, 2016).

Related to the success of text-based learning in the 2013 curriculum, the portrait of fifth-grade students' explanatory writing skills was quite successful in generating ideas (see table 1 which shows 68.7\%). But knowledge and understanding of science still need to be increased so that students can connect everyday language with scientific language (Chen et al., 2013). Moreover, there are no students who are able to generate content ideas well. The student's writing skills document shows that no student is able to write an opinion sentence. Their writings only contain explanations of the human circulatory system. Even though the explanatory text ends with a conclusion that contains the author's opinion about the phenomenon described (Priyatni, 2014, p. 83). In this regard, language teachers must be aware of the stimulation that can be used to arouse students' interest in writing, for example, visual stimuli, oral stimuli, reading, and different forms and viewpoints (Okari, 2016). With this stimulation, it is expected that students will be able to write opinion sentences in response to the phenomenon described.

\subsection{Content Organization}

Table 1 shows that only $9.6 \%$ were able to organize the contents of ideas well. Ideas are written in a logical order, are dense in information, and fulfil the cohesion element of paragraph coherence. The content development done by most students is $51.6 \%$ of students is not logical. Even the main idea of the paragraph is not visible. However, there are still $25.8 \%$ of students who have been able to organize content adequately even though the information is written is incomplete. Unfortunately, there are still $13 \%$ of students whose essays are not communicative and disorganized. For example, they only mention the sequence of the circulatory process without fulfilling the paragraph formation requirements.

Organizing the contents is very necessary for writing so that the essay is cohesive and coherent. In writing assignments, content areas are referred to as a means to improve students' cognitive abilities to speak and reason in the learning environment (Miller, Scott, \& McTigue, 2018). Both as a product and as a process, writing is an individual cognitive activity that reflects individual phenomenology. Every author's actions will produce meaning (Balta, 2018). Therefore, the inappropriate organization of contents will produce different meanings. As did $38.7 \%$ of students in this study. They do not write links between sentences and paragraphs that make the main idea/meaning blurred. Therefore, it is important for writers to arrange the table of contents before they compile the writing (Lantsoght, 2018).

Related to the success of text learning in the 2013 curriculum, a portrait of content organization is sufficient for explanatory writing skills (see table 1 which shows 62.4\%). Even so, the content development undertaken by most students is still low. It is proven that only $9.6 \%$ of students are able to write cohesive and coherent essays. Writing is a language skill that involves higher-order thinking skills. This is the biggest reason for writing difficulties, a namely cognitive activity that is carried out, repeated, and arranged at one time (Balta, 2018). The cohesion and coherence of essays become the academic 
challenge of students in writing explanations. Cohesion is only a guide to coherence in the act of reading. While coherence is in the reader, not the writer (Kılıç et al., 2016). Related to that, Okari (2016) suggested the following strategies can be applied in teaching writing skills, namely (1) developmental sequences consisting of imitation, copying, and independent writing, (2) developmental orders that teach the use of capital and small letters. Then, the third strategy is game-based multi-sensory teaching.

\subsection{Vocabulary}

Table 1 shows that only 13\% mastered the use of conjunctions, both in the form of conjunctions and those that showed cause-effect relationships. There are still many students who still often write words that can damage meaning. For example, in one sentence there are several conjunctions which are not cohesive. As many as $29 \%$ of students also sometimes do not choose the right words and phrases, although it does not damage the meaning of the sentence. There are still students who are careless in the use of vocabulary which is $19.3 \%$. They only write the outline with a short answer so that it doesn't form a paragraph at all.

Explanation writing is writing a text that explains the processes related to natural, social, scientific, cultural and other phenomena (Priyatni, 2014, p. 82). While the human circulatory system is used as the topic in this study. Therefore knowledge and understanding of the language of science are the main components in the essay. The explanatory writing skills document also shows that only $13 \%$ are able to apply scientific language to essays well.

Explanation text has characteristics that distinguish it from other types of texts. The explanatory text contains elements of the title, general statement, explanatory row, and conclusion (Mahsun, 2014, p. 98). In addition, there are linguistic characteristics in explanatory texts that include terms and sentence structures using conjunctions that indicate causal relations (Priyatni, 2014, p. 85). The students' explanatory writing skills document shows that the use of sequence conjunctions is still very limited. They tend to focus on the choice of words related to the human circulatory system. Scientific language is only meaningful when used in authentic contexts. While students bring their own daily language to science classes, science as a discipline uses their own special language with certain functions (Chen et al., 2013).

Related to the achievement of text-based learning in the 2013 curriculum, the vocabulary aspect in the assessment of essay writing skills was considered quite successful. This can be seen in Table 1 that the average achievement of vocabulary reached $63.5 \%$. However, the majority of students' vocabulary mastery is still low. proven in table 1 that only $13 \%$ of students have good vocabulary mastery. Acquisition of writing skills among students must be seen and practised as a process (Okari, 2016). The writing process is related to how to organize selected ideas, information, facts, and others as a reflection of one's mindset through effective reasoning and use of language
(Slamet, Waluyo, \& Suyanto, 2014, p. 1). Therefore, the teacher must guide the stages of writing students such as generating ideas, structuring, drafting, focusing, evaluating, and reviewing (Tanyeli Zeki \& Kuter, 2017).

\subsection{Language Development}

Table 1 shows that only $9.6 \%$ were able to develop languages with complex but effective constructs. As many as $25.8 \%$ of students can develop language even though it is still simple. As many as $42 \%$ of the students' sentences were unable to represent the concept maps they had made in the essay so that the meaning was blurred. For example, there is no confirmation in the sentence whether the sentence describes the small or large circulatory system. There are still $22.5 \%$ of students who only write concept maps without forming sentences. Although elementary school students are encouraged to complete written records, they are permitted to use alternative forms of literacy such as drawing (Lee, 2017). The teacher's interview results also showed that the teacher allows students to draw concept maps in writing explanations. The reason is, at least students have a description of the explanation related to the human circulatory system. During elementary school, the process of generating ideas and planning was mixed with the process of handwriting (Longobardi, Spataro, \& Pizzicannella, 2018).

Students who are in the category of good to middle indicate that they are able to develop language even though most of the development is still simple. In fact, writing is a cyclic process that moves writers both forward and backward to create meaning (Tanyeli Zeki \& Kuter, 2017). Tanyeli Zeki and Kuter also explained that there were several stages in writing, namely generating ideas, structuring, drafting, focusing, evaluating, and reviewing. The stages are interrelated and interdependent and can change their place during the process if necessary. In teaching activities there are also six levels that are directly linked to students' cognitive thinking, namely memorizing, understanding, using, analyzing, integrating, and evaluating (Zhang, Zhu, \& Wan, 2018). Based on this, it can be seen that the process of developing writing is built on the next stage (Casey, Miller, Stockton, \& Justice, 2016).

Related to the achievement of text learning in the 2013 curriculum, aspects of language development reached the lowest percentage among other aspects of $56.25 \%$ (see table 1). Although concept maps created by students are already able to represent explanations, teaching writing includes elements of theory both the simple and not-so-simple theories of writing development (Little, Clark, Tani, \& Connor, 2018). The teacher also needs to train students to write concept map explanations. Students can also be trained to develop sequence-based concept maps. Thus, students begin to write sentence by sentence which gradually becomes a paragraph. Kılıç et al (2016) suggested that the order of sentences in a discourse can form the main idea called the topic of discourse. The topic of discourse is developed through subordinate ideas or subtopics, both directly and indirectly. Thus, subtopics that are organized 
hierarchically contribute to the development of the topic of discourse and it seems that most of the sentences that form a subtopic form the order in which the discourse continues. Students can increase the effectiveness and efficiency of exercises and writing activities only if they understand the instructions (Zhang et al., 2018).

\subsection{Mechanic}

Table 1 shows that only $9.6 \%$ mastered spelling and writing. They understand when to use bunches, commas, and the use of capital letters and other mechanisms. While other students make mechanical mistakes sometimes that do not damage the meaning of the sentence. However, mechanical understanding in $22.5 \%$ of students is still lacking. Writing involves a 'coherent' combination of high-level skills such as planning and organizing with low-level skills such as spelling, punctuation, and choice of words (Kılıç et al., 2016). Quality writing involves more than just spelling, writing neatly, and punctuating correctly. Students must be able to articulate ideas clearly using nouns, verbs, adjectives, and other parts of the conversation; formulate a sentence that makes sense; and write sentences that are on the suggested topic (Casey et al., 2016). Good handwriting, proper spelling, and proper punctuation are the main skills needed to write well (Okari, 2016).

Related to the achievement of text-based learning in the 2013 curriculum, the mechanical aspects of writing skills assessment can be categorized quite successfully. This is shown in table 1 that the average mechanical mastery of students reaches $63.2 \%$. However, it is a special concern again that only $9.6 \%$ are able to master the mechanism in writing skills. That is, further efforts are needed in learning writing skills. Basic writing skills such as spelling and handwriting require skills in phonological awareness and rapid drawing of letters and processing of orthographic information and fine motor skills (Decker et al., 2016). Regarding limited language skills, which must always be considered when analyzing student results, the types of language errors deserve special attention because their treatment will differ depending on their nature (Otto, 2018). This is where the teacher guides students in all class procedures and activities by giving comments and encouragement (Barrot, 2015).

\section{CONCLUSION}

Based on the results of research and discussion, a portrait of students' explanatory writing skills can be categorized quite successfully in all aspects. But only the aspect of content ideas was able to reach the category of success because it reached a percentage of $68.7 \%$. Even so, there are still many student ideas that are considered incomplete in writing explanations about the human circulatory system. It is proven that there are no students who are able to reach a good category in writing information. Paragraph cohesion and coherence are the biggest difficulties for students in writing. Moreover, the concept of explanatory texts is a combination of content and linguistic analysis that shows the demands of scientific concepts and language of students in constructing explanations about certain topics (Seah, 2016). So, students' explanatory texts can represent the extent to which students acquire scientific knowledge and apply them in explanatory texts.

Writing as a form of literacy is not only an academic skill to be mastered but also as a social practice. In this case, writing reflects our life experience. This relates to what we do, what we see, what we believe in, how we feel, etc. (Lee, 2017). Knowledge comprehension, processing speed, and auditory processing are moderate to strong predictors in written expression skills throughout development (Decker et al., 2016). Moreover, PISA 2018 marks the third time that reading literacy is considered as a reflection of how students obtain and use information across a broad context (OECD, 2018). Through the portrait of writing skills in this research, besides we can find out the extent of the success of text learning in the 2013 curriculum, we can also know the extent to which students' language skills can affect their learning outcomes. This is because writing skills can be mastered by students after they have mastered listening, speaking and reading skills (Slamet, 2017, p. 105). Not only that, the type of explanatory text can represent students' scientific knowledge. Writing should not only be taught as an academic skill in school.

\section{REFERENCES}

Arikunto, S. (2013). Dasar-dasar Evaluasi Pendidikan. Jakarta: Bumi Aksara.

Balta, E. E. (2018). The Relationships Among Writing Skills, Writing Anxiety and Metacognitive Awareness. Journal of Education and Learning, 7(3), 233-241. https://doi.org/10.5539/jel.v7n3p233

Barrot, J. (2015). A Sociocognitive-Transformative Approach to Teaching Writing. Indonesian Journal of Applied Linguistics, 4(2), 132-122.

Casey, L. B., Miller, N. D., Stockton, M. B., \& Justice, W. V. (2016). Assessing Writing in Elementary Schools: Moving Away From a Focus on Mechanics. Language Assessment Quarterly, 13(1), 42-54. https://doi.org/10.1080/15434303.2015.1136311

Chen, Y. C., Hand, B., \& Mcdowell, L. (2013). The Effects of Writing-to-Learn Activities on Elementary Students' Conceptual Understanding: Learning about Force and Motion Through Writing to Older Peers. Science Education, 97(5), 745-771.

https://doi.org/10.1002/sce.21067

Dağ, N. (2017). The Reading Profile of Turkish Primary School Students. International Journal of Instruction, 10(4), 293-306.

Decker, S. L., Roberts, A. M., Roberts, K. L., Stafford, A. L., \& Eckert, M. A. (2016). Cognitive Components of 
Developmental Writing Skill. Psychology in the Schools, 53(6), 617-625. https://doi.org/10.1002/pits.21933

Figueroa, J., Meneses, A., \& Chandia, E. (2018). Academic language and the quality of written arguments and explanations of Chilean 8th graders. Reading and Writing, 31(3), 703-723. https://doi.org/10.1007/s11145-017-9806-5

Gu, M. (2017). Text-Based Teaching in a Year 8 Chinese. In L. E. Mickan P. (Ed.), Text-Based Research and Teaching (pp. 157-178). London: Palgrave Macmillan.

Kitcher, P. (1989). Explanatory Unification and the Causal Structure of the World. Minneapolis: University of Minnesota Press.

Kılıç, M., Genç, B., \& Bada, E. (2016). Topical Structure in Argumentative Essays of EFL Learners and Implications for Writing Classes. Journal of Language and Linguistic Studies, 12(2), 107-116. Retrieved from www.jlls.org

Kusmana, L. (2014). Kreativitas Menulis. Yogyakarta: Ombak.

Lantsoght, E. O. L. (2018). Honing Your Academic Writing Skills. In: The A-Z of the PhD Trajectory. Springer Texts in Education (pp. 109-136). Cham: Springer. https://doi.org/10.1007/978-3-319-77425-1_7

Lee, C.-J. (2017). Learning to Teach through Writing with Students. Language and Literacy, 19(4), 112-128.

Li, H., Gobert, J., \& Dicker, R. (2017). Dusting Off The Messy Middle: Assessing Students' Inquiry Skills Through Doing and Writing. In Lecture Notes in Computer Science (including subseries Lecture Notes in Artificial Intelligence and Lecture Notes in Bioinformatics) (pp. 175-187). Cham: Springer. https://doi.org/10.1007/978-3-319-61425-0_15

Little, C. W., Clark, J. C., Tani, N. E., \& Connor, C. M. (2018). Improving Writing Skills Through Technology-based Instruction: A Meta-analysis. Review of Education, 6(2), 183-201. https://doi.org/10.1002/rev3.3114

Longobardi, E., Spataro, P., \& Pizzicannella, E. (2018). Handwriting, Spelling, and Narrative Competence in The Fictional Stories of Italian Primary-school Children. European Journal of Psychology of Education, 33(2), 277-293. https://doi.org/10.1007/s10212-017-0328-y

Mahsun. (2014). Teks dalam Pembelajaran Bahasa Indonesia Kurikulum 2013. Jakarta: Rajawali Press.

Maryanto. (2013). Bahasa Indonesia Ekspresi Diri dan Akademik. Jakarta: Kementerian Pendidikan dan Kebudayaan.

Miller, D. M., Scott, C. E., \& McTigue, E. M. (2018). Writing in the Secondary-Level Disciplines: a Systematic Review of Context, Cognition, and Content. Educational Psychology Review, 30(1), 83-120. https://doi.org/10.1007/s10648-016-9393-z

Milles, M. B., \& Huberman, A. M. (1992). Analisis Data Kualitatif. (T. R. Rohidi \& Mulyarto, Eds.). Jakarta: Universitas Indonesia Press.

Nurgiyantoro, B. (2013). Penilaian Pembelajaran Bahasa Berbasis Kompetensi. Yogyakarta: BPFE Yogyakarta.

Okari, F. M. (2016). The Writing Skill in The Contemporary Society: The Kenyan Perspective. Journal of Education and Practice, 7(35). Retrieved from www.iiste.org

Otto, A. (2018). Assessing Language in Content and Language Integrated Learning: A Review of the Literature towards a Functional Model. Latin American Journal of Content and Language Integrated Learning, 11(2), 308-325. https://doi.org/10.5294/laclil.2018.11.2.6

Priyatni, E. (2014). Desain Pembelajaran Bahasa Indonesia dalam Kurikulum 2013. Jakarta: Bumi Aksara.

Slamet, S. Y. (2017). Pembelajaran Bahasa dan Sastra Indonesia di Kelas Rendah dan Kelas Tinggi Sekolah Dasar. Surakarta: UNS Press.

Slamet, S. Y., Waluyo, H. J., \& Suyanto, M. I. (2014). Metode Menulis Karya Ilmiah. Surakarta: UNS Press.

Tanyeli Zeki, N., \& Kuter, S. (2017). Impact of Collaborative and Reflective Writing Activities on Students' Autonomy in Writing. Quality and Quantity, pp. 1-18. https://doi.org/10.1007/s11135-017-0615-3

Zhang, M., Zhu, W., \& Wan, M. (2018). Corpus-based Evaluation on Instrumental Texts in Textbook. Higher Education Studies, 8(3), 104-112. https://doi.org/10.5539/hes.v8n3p104 